\title{
ISOPRENOID QUINONE COMPOSITION IN THE CLASSIFICATION OF RHODOSPIRILLACEAE
}

\author{
AKIRA HIRAISHI, YASUO HOSHINO AND HIROSHI KITAMURA² \\ Department of Biology, Faculty of Science, Tokyo Metropolitan \\ University, Setagaya-ku, Tokyo 158, Japan
}

(Received April 16, 1984)

Fifty five strains of 13 species of Rhodospirillaceae and one strain of Chromatium vinosum were examined for isoprenoid quinone composition. These bacteria were divided into the following five categories on the basis of their predominant quinone patterns: Q-10-Rhodospirillum rubrum, Rhodopseudomonas palustris, Rhodopseudomonas capsulata, Rhodopseudomonas sphaeroides, and Rhodopseudomonas sulfidophila; Q-10+MK-10 Rhodopseudomonas acidophila; Q-9+MK-9 - Rhodospirillum fulvum, Rhodospirillum molischianum, Rhodopseudomonas viridis, and Rhodopseudomonas globiformis; Q-8 - Rhodospirillum photometricum and atypical strains of Rhodopseudomonas gelatinosa; Q-8+-MK-8 - Rhodospirillum tenue, $R$. gelatinosa, and $C$. vinosum. The significance of the quinone system in Rhodospirillaceae taxonomy is discussed in comparison with available information on other taxonomic properties such as morphology and photosynthetic membrane systems and on some phylogenetic characteristics.

Respiratory isoprenoid quinones are essential components of membranebound electron transport systems in bacteria. In addition to interest in their functions in electron transport mechanisms, a growing concern with the significance of the quinone system in bacterial systematics has led to intensive study. At present, the diagnostic value of isoprenoid quinones in bacterial taxonomy is well realized (1), and an analysis of isoprenoid quinone composition of bacterial strains is one of the most prevalent chemotaxonomic methods (2).

There are some preliminary reports in the literature on predominant quinone patterns in phototrophic purple nonsulfur bacteria, Rhodospirillaceae (3-5). The available information on this subject has also been summarized in recent re-

1 This study was presented in part at the Annual Meeting of the Society of Fermentation Technology, Japan, Osaka, 1983.

2 Present address: College of Industrial Technology, Nihon University, Narashino, Chiba 275, Japan. 
Table 1. Bacterial strains studied.

\begin{tabular}{|c|c|c|c|}
\hline $\begin{array}{l}\text { Species and } \\
\text { strain designation }\end{array}$ & $\begin{array}{c}\text { Other } \\
\text { designations }\end{array}$ & Source $^{b}$ & Reference \\
\hline \multicolumn{4}{|l|}{ Rhodospirillum rubrum } \\
\hline *ATCC 11170 & DSM 467 & ATCC & \\
\hline IFO 3986 & & IFO & \\
\hline SW20 & & HiRaishi \& KitAMURA & (8) \\
\hline \multicolumn{4}{|l|}{ Rhodospirillum tenue } \\
\hline$* 2761$ & $\begin{array}{l}\text { ATCC } 25093 \text {, } \\
\text { DSM } 109\end{array}$ & N. Pfennig & (30) \\
\hline SW18 & & HiRAishi \& KitAmURA & (8) \\
\hline \multicolumn{4}{|l|}{ Rhodospirillum fulvum } \\
\hline WP1 & & Hiraishi \& Kitamura & (8) \\
\hline WF2 & & Hiraishi \& KitAMURA & (8) \\
\hline WF4 & & HiRAISHI \& KitAMURA & $(8)$ \\
\hline WF6 & & Hiraishi \& Kitamura & (8) \\
\hline \multicolumn{4}{|c|}{ Rhodospirillum molischianum } \\
\hline$* \mathrm{~N} 131$ & $\begin{array}{l}\text { ATCC } 14031 \text {, } \\
\text { DSM } 120\end{array}$ & N. Pfennig & \\
\hline \multicolumn{4}{|c|}{ Rhodospirillum photometricum } \\
\hline IL256 & & our own collection & \\
\hline WP4 & & Hiraishi \& Kitamura & (8) \\
\hline WP5 & & HiRAishi \& KitAmuRa & (8) \\
\hline WP6 & & HiRaishi \& KitAmURA & (8) \\
\hline \multicolumn{4}{|c|}{ Rhodopseudomonas palustris } \\
\hline *ATCC 17001 & DSM 126 & A. YoSHIKAWA & \\
\hline A & & H. TAKAHASHI & $(31)$ \\
\hline IL137 & & our own collection & \\
\hline RS22 & & HiRAishi \& KitAMURA & (8) \\
\hline SA37 & & Hiraishi \& Kitamura & (8) \\
\hline $\mathrm{SA} 42$ & & Hiraishi \& Kitamura & (8) \\
\hline \multicolumn{4}{|l|}{ Rhodopseudomonas viridis } \\
\hline$* \mathrm{~F}$ & $\begin{array}{l}\text { ATCC } 19567 \text {, } \\
\text { DSM } 133\end{array}$ & N. Pfennig & \\
\hline NR7 & & our own collection & \\
\hline \multicolumn{4}{|c|}{ Rhodopseudomonas acidophila } \\
\hline *ATCC 25092 & DSM 137 & ATCC & (9) \\
\hline PT1 & & our own collection & \\
\hline PT6 & & our own collection & \\
\hline NR9 & & our own collection & \\
\hline \multicolumn{4}{|c|}{ Rhodopseudomonas globiformis } \\
\hline *DSM 161 & & DSM & (11) \\
\hline \multicolumn{4}{|c|}{ Rhodopseudomonas gelatinosa } \\
\hline *ATCC 17011 & & ATCC & \\
\hline A3 & & H. TAKAHASHI & (32) \\
\hline IL144 & & our own collection & \\
\hline KA49 & & Hiraishi \& KitAMURA & (8) \\
\hline KE2 & & our own collection & \\
\hline
\end{tabular}


Table 1. (Continued)

\begin{tabular}{|c|c|c|c|}
\hline $\begin{array}{c}\text { Species and } \\
\text { strain designation }^{a}\end{array}$ & $\begin{array}{c}\text { Other } \\
\text { designations }\end{array}$ & Source $^{b}$ & Reference \\
\hline FR2 & & Hiraishi \& KitAmURA & (8) \\
\hline FR3 & & Hiraishi \& Kitamura & $(8)$ \\
\hline SA34 & & Hiraishi \& Kitamura & (8) \\
\hline \multicolumn{4}{|c|}{ Rhodopseudomonas capsulata } \\
\hline $\begin{array}{l}\text { *ATCC } 11166 \\
\text { IL155 }\end{array}$ & & $\begin{array}{l}\text { A. YoshiKaWA } \\
\text { our own collection }\end{array}$ & \\
\hline HP8 & & Hiraishi \& KitAmura & $(8)$ \\
\hline $\mathrm{C} 2$ & & HIRAISHI \& KITAMURA & $(8)$ \\
\hline MC9R & & our own collection & \\
\hline SA47 & & HIRAISHI \& Kitamura & $(8)$ \\
\hline \multicolumn{4}{|c|}{ Rhodopseudomonas sphaeroides } \\
\hline *ATCC 17023 & & ATCC & \\
\hline IFO 12203 & & IFO & \\
\hline B1 & & H. TAKaHASHI & (32) \\
\hline B3 & & H. TAKAHASHI & (32) \\
\hline IL102 & & our own collection & \\
\hline RS1 & & HIRAISHI \& KITAMURA & (8) \\
\hline RS2 & & Hiraishi \& Kitamura & (8) \\
\hline TWN & & HIRAISHI \& KitAMURA & (8) \\
\hline C7 & & HIRAISHI \& KITAMURA & (8) \\
\hline KA38 & & Hiraishi \& Kitamura & (8) \\
\hline KA63 & & HIRAISHI \& KitAMURA & (8) \\
\hline NR3 & & Hiraishi \& KitAMURA & $(8)$ \\
\hline \multicolumn{4}{|c|}{ Rhodopseudomonas sulfidophila } \\
\hline $\begin{array}{l}* \text { W4 } \\
\text { TW13 }\end{array}$ & DSM 1374 & $\begin{array}{l}\text { T. A. HANSEN } \\
\text { our own collection }\end{array}$ & $(10)$ \\
\hline \multicolumn{4}{|l|}{ Chromatium vinosum } \\
\hline$* \mathrm{D}$ & $\begin{array}{l}\text { ATCC } 17899 \text {, } \\
\text { DSM } 180\end{array}$ & K. Shimada & \\
\hline
\end{tabular}

a Type or neotype strains are asterisked.

$b$ ATCC, American Type Culture Collection, Rockville, U.S.A.; IFO, Institute for Fermentation, Osaka, Japan; DSM, Deutsche Sammlung von Mikroorganismen, Göttingen, Federal Republic of Germany; N. Pfennig, Universität Konstanz, Konstanz, Federal Republic of Germany; A. Yoshikawa, Mitsubishi Gas Chemical Co., Niigata, Japan; H. Takahashi, Tohoku University, Sendai, Japan; T. A. Hansen, University of Groningen, Haren, The Netherlands; K. Shimada, Tokyo Metropolitan University, Tokyo, Japan.

views $(1,6)$. These reports have shown that ubiquinones (Q-8, Q-9, or Q-10) represent the major quinones within representative species of Rhodospirillaceae, and some species of these bacteria also contain menaquinones (MK-8 or MK-9) with polyprenyl side chains of the same length as the present ubiquinones. However, it is not yet possible to establish the taxonomic significance of isoprenoid quinones in Rhodospirillaceae because no detailed information regarding the quinone system is available for several species (6) such as Rhodospirillum photo- 
metricum, Rhodopseudomonas acidophila, Rhodopseudomonas globiformis, and Rhodopseudomonas sulfidophila and also because no attempt has been made to relate this system to other well-defined taxonomic properties.

This article deals with the quinone system in 13 species of Rhodospirillaceae and, for comparison, one species of Chromatiaceae. The significance of isoprenoid quinones in Rhodospirillaceae taxonomy is discussed in comparison with available information on other taxonomic properties such as morphology and intracytoplasmic membrane systems and on some phylogenetic characteristics.

\section{MATERIALS AND METHODS}

Strains and cultivation. Details of the bacterial strains tested and their sources are listed in Table 1. The species and strain names are used according to their designations with which we received them from culture collections and individuals. All names of the bacterial species referred to here are described in the Approved Lists of Bacterial Names (7).

Unless otherwise indicated, mineral base RM2 (pH 7.0) (8) was used for all growth media. DL-Sodium malate $(3.6 \mathrm{~g} / l)$ and yeast extract $(0.5 \mathrm{~g} / l)$ were the usual carbon source and growth factors, respectively. The medium for Rhodospirillum fulvum, Rhodospirillum molischianum, and $R$. photometricum was supplemented with filter-sterilized sodium ascorbate $(0.5 \mathrm{~g} / l)$. The $\mathrm{pH}$ of the medium for $R$. acidophila was adjusted to $5.8(9)$. The medium for $R$. sulfidophila contained a high concentration of $\mathrm{NaCl}(25 \mathrm{~g} / l)(10)$. $\quad R$. globiformis was cultured according to Pfennig (11). The organisms were grown in completely filled screw-capped bottles $(280 \mathrm{ml})$ at $30^{\circ}$ under incandescent illumination (ca. 5,000 lx). Cultures at the early stationary phase of growth were harvested by centrifugation, washed with distilled water, and stored at $0-4^{\circ}$ until assayed, not more than $3 \mathrm{hr}$.

Extraction and purification of quinones. Preliminary experiments established that higher concentrations of isoprenoid quinones were often obtained from fresh wet cells than from freeze-dried cells of the same strains. In this study, therefore, quinones were extracted directly from fresh stationary cells in all cases. The quinone extraction was made with chloroform-methanol $(2: 1, \mathrm{v} / \mathrm{v})$ according to Collins et al. (12). The total quinone extracts were purified by thin-layer chromatography (TLC) using Whatman PK6F silica gel plates and a developing solvent of petroleum benzine-diethyl ether $(9: 1, \mathrm{v} / \mathrm{v})(2)$; as markers, available Q-10 and vitamin $\mathrm{K}_{1}$ were co-chromatographed. The ubiquinone and menaquinone samples obtained were further purified by TLC on the same plates developed in $100 \%$ benzene and hexane-benzene-chloroform $(5: 2: 1, \mathrm{v} / \mathrm{v})$, respectively (2).

Spectrophotometric analysis. Ultraviolet absorption spectra of quinone samples in ethanolic solution were recorded with a Hitachi 200-20 spectrophotometer. Quinone concentration was determined by the difference spectrum of the reduced minus the oxidized state, using the following millimolar extinction coef- 
ficients: ubiquinone, $\Delta \varepsilon_{275 \mathrm{~nm}}=12.9 \mathrm{~mm}^{-1} \mathrm{~cm}^{-1} ;$ menaquinone, $\Delta \varepsilon_{245 \mathrm{~nm}}=28.7$ $\mathrm{mM}^{-1} \mathrm{~cm}^{-1}$ (13).

Reversed-phase TLC. Components of quinone samples were separated by reversed-phase TLC using Whatman LKC18F plates with acetone-water (95: 5, $\mathrm{v} / \mathrm{v}$, for ubiquinone; $98: 2, \mathrm{v} / \mathrm{v}$, for menaquinone) as the solvent system. The separated quinone homologues were detected as yellow-colored bands in visual light and as fluorescence-quenched regions in $254 \mathrm{~nm}$ ultraviolet light, and then identified by comparison with known quinones co-chromatographed. Scanning patterns of the quinone chromatograms were obtained with a Helena Quick Scan $\mathrm{R} \& \mathrm{D}$ densitometer and their relative percentage to the total peak area was calculated.

High-performance liquid chromatography (HPLC). The number of isoprene units and the relative percentage of components of quinone samples were also determined by HPLC which was performed on a Shimadzu Liquid Chromatograph LC-3A equipped with a Zobax ODS pre-packed column, a Shimadzu Spectrophotometric Detector SPD-2A, and a microcomputer, Shimadzu Chromatopac C-RIA; solvent, methanol-isopropyl ether $(3: 1, \mathrm{v} / \mathrm{v})$; solvent flow, $1 \mathrm{ml} / \mathrm{min}$. This system was identical with that of TAMAOKA et al. (14).

Standard quinones. Vitamin $\mathrm{K}_{1}$ and ubiquinone standards (Q-6 through Q-10) were obtained from Sigma Chemical Co., except Q-8 which was prepared from Flavobacterium lutescens IFO $12997(15)$. Q-10 $\left(\mathrm{H}_{2}\right)$ was kindly supplied by Dr. H. Kuraishi. Reference menaquinones were prepared from Cytophaga aquatilis IAM 12365 (MK-6) (15), Cytophaga heparina IFO 12017 (MK-7) (15, 16), Curtobacterium testaceum IAM 1537 (MK-8 through MK-11) (14), and Arthrobacter globiformis IFO $12137\left(\mathrm{MK}-9\left(\mathrm{H}_{2}\right)\right)(14,17)$.

\section{RESULTS}

Chromatographic and spectrophotometric behavior of quinones

In the TLC system with the solvent of petroleum benzine-diethyl ether $(9: 1$,

Table 2. $R f$ values (on reversed-phase TLC) and HPLC retention times of standard quinone homologues.

\begin{tabular}{lcclcc}
\hline Ubiquinone & $R f$ & $\begin{array}{c}\text { HPLC } \\
\text { retention } \\
\text { time (min) }\end{array}$ & Menaquinone & $R f$ & $\begin{array}{c}\text { HPLC } \\
\text { retention } \\
\text { time (min) }\end{array}$ \\
\hline Q-6 & 0.55 & 6.2 & MK-6 & 0.61 & 9.5 \\
Q-7 & 0.49 & 7.7 & MK-7 & 0.56 & 12.2 \\
Q-8 & 0.42 & 9.7 & MK-8 & 0.50 & 15.8 \\
Q-9 & 0.36 & 12.5 & MK-9 & 0.45 & 20.5 \\
Q-10 & 0.29 & 16.1 & MK-9 $\left(\mathrm{H}_{2}\right)$ & NT $^{a}$ & 23.1 \\
Q-10 $\left(\mathrm{H}_{2}\right)$ & $\mathrm{NT}$ & 17.6 & MK-10 & 0.40 & 27.2 \\
& & & MK-11 & 0.35 & 36.6 \\
\hline
\end{tabular}

a Not tested. 
Table 3. Quinone composition of Rhodospirillaceae

\begin{tabular}{|c|c|c|c|c|c|c|c|c|}
\hline \multirow[b]{2}{*}{ Organism } & \multirow{2}{*}{$\begin{array}{c}\text { Total } \\
\text { ubiquinone } \\
\text { content } \\
(\mu \mathrm{mol} / \mathrm{g} \\
\text { dry wt) }\end{array}$} & \multicolumn{7}{|c|}{ Percentage of total ubiquinones ${ }^{a}$} \\
\hline & & Q-6 & Q-7 & Q-8 & Q-9 & Q-10 & $\begin{array}{l}\text { Q-10 } \\
\left(\mathrm{H}_{2}\right)\end{array}$ & Others $^{b}$ \\
\hline \multicolumn{9}{|c|}{ Rhodospirillum rubrum } \\
\hline ATCC 11170 & 2.02 & & & & (5) & (93) & & (2) \\
\hline IFO 3986 & 5.27 & & & $\mathbf{t}^{c}$ & 5 & 92 & & 3 \\
\hline SW20 & 5.17 & & & $\mathrm{t}$ & 6 & 92 & & 1 \\
\hline \multicolumn{9}{|l|}{ Rhodospirillum tenue } \\
\hline 2761 & 2.99 & $\mathrm{t}$ & 3 & 94 & 1 & & & 1 \\
\hline SW18 & 2.87 & $\mathrm{t}$ & 3 & 93 & 1 & & & 2 \\
\hline \multicolumn{9}{|c|}{ Rhodospirillum fulvum } \\
\hline WP1 & 4.00 & & $\mathrm{t}$ & 4 & 89 & 2 & & 4 \\
\hline WF2 & 3.38 & & $\mathrm{t}$ & 5 & 90 & 2 & & 3 \\
\hline WF4 & 4.33 & & $\mathrm{t}$ & 4 & 89 & 2 & & 5 \\
\hline WF6 & 5.12 & & $\mathrm{t}$ & 3 & 92 & 2 & & 3 \\
\hline \multicolumn{9}{|c|}{ Rhodospirillum molischianum } \\
\hline $\mathrm{N} 131$ & 3.50 & & $\mathrm{t}$ & 3 & 89 & 2 & & 6 \\
\hline \multicolumn{9}{|c|}{ Rhodospirillum photometricum } \\
\hline IL256 & $\mathbf{N D}^{d}$ & & 7 & 89 & 4 & & & \\
\hline WP4 & 3.78 & & 8 & 90 & 2 & & & \\
\hline WP5 & 3.24 & & 6 & 87 & 2 & & & 5 \\
\hline WP6 & 4.28 & & 5 & 91 & 4 & & & \\
\hline \multicolumn{9}{|c|}{ Rhodopseudomonas palustris } \\
\hline ATCC 17001 & 2.59 & & & & 2 & 98 & & \\
\hline A & 2.97 & & & & 3 & 96 & & 1 \\
\hline IL137 & 2.98 & & & & 3 & 97 & & $\mathrm{t}$ \\
\hline RS22 & 2.17 & & & $\mathrm{t}$ & 3 & 96 & & $\mathrm{t}$ \\
\hline SA37 & ND & & & & 2 & 98 & & \\
\hline SA42 & ND & & & & 2 & 97 & & $\mathrm{t}$ \\
\hline \multicolumn{9}{|c|}{ Rhodopseudomonas viridis } \\
\hline $\mathrm{F}$ & 2.53 & & & (2) & (94) & (4) & & \\
\hline NR7 & 2.26 & & & 5 & 93 & 2 & & \\
\hline \multicolumn{9}{|c|}{ Rhodopseudomonas acidophila } \\
\hline ATCC 25092 & 4.88 & & & & 3 & 97 & & $\mathrm{t}$ \\
\hline PT1 & 3.36 & & & & 4 & 94 & 1 & $\mathrm{t}$ \\
\hline PT6 & 2.87 & & & & 4 & 94 & 1 & $\mathbf{t}$ \\
\hline NR9 & 2.43 & & & & 8 & 92 & & $\mathrm{t}$ \\
\hline \multicolumn{9}{|c|}{ Rhodopseudomonas globiformis } \\
\hline DSM 161 & ND & & & (5) & (93) & (2) & & \\
\hline \multicolumn{9}{|c|}{ Rhodopseudomonas gelatinosa } \\
\hline ATCC 17011 & 2.38 & & $\mathrm{t}$ & 91 & 1 & $\mathrm{t}$ & & 7 \\
\hline A3 & 4.05 & & $\mathrm{t}$ & 97 & 1 & & & 1 \\
\hline IL144 & 2.44 & & $\mathrm{t}$ & 97 & 2 & & & $\mathrm{t}$ \\
\hline KA49 & 2.39 & & $\mathrm{t}$ & 98 & 1 & & & $t$ \\
\hline KE2 & 2.36 & & 4 & 90 & 2 & & & 4 \\
\hline
\end{tabular}


species and Chromatium vinosum.

\begin{tabular}{|c|c|c|c|c|c|c|c|c|}
\hline \multirow{2}{*}{$\begin{array}{c}\text { Total } \\
\text { menaquinone } \\
\text { content } \\
(\mu \mathrm{mol} / \mathrm{g} \\
\text { dry wt) }\end{array}$} & \multicolumn{8}{|c|}{ Percentage of total menaquinones ${ }^{a}$} \\
\hline & MK-6 & MK-7 & MK-8 & MK-9 & MK-9 $\left(\mathrm{H}_{2}\right)$ & MK-10 & MK-11 & Others $^{b}$ \\
\hline $\begin{array}{l}\text { absent } \\
\text { absent } \\
\text { absent }\end{array}$ & & & & & & & & \\
\hline 0.91 & 2 & 2 & 89 & $\mathrm{t}$ & & & & 6 \\
\hline 0.88 & 1 & 1 & 88 & $\mathrm{t}$ & & & & 9 \\
\hline 0.68 & $\mathrm{t}$ & & 6 & 89 & $\mathrm{t}$ & $\mathrm{t}$ & & 4 \\
\hline 0.75 & 1 & & 6 & 84 & $\mathrm{t}$ & $\mathrm{t}$ & & 8 \\
\hline 0.61 & $\mathrm{t}$ & & 6 & 90 & & & & 4 \\
\hline 1.11 & $\mathrm{t}$ & & 4 & 91 & & $\mathrm{t}$ & & 5 \\
\hline 1.22 & $\mathrm{t}$ & & 5 & 87 & 2 & 1 & & 4 \\
\hline $\begin{array}{l}\text { absent } \\
\text { absent } \\
\text { absent } \\
\text { absent }\end{array}$ & & & & & & & & \\
\hline $\begin{array}{l}\text { absent } \\
\text { absent } \\
\text { absent } \\
\text { absent } \\
\text { absent } \\
\text { absent }\end{array}$ & & & & & & & & \\
\hline 0.98 & & (1) & (6) & (93) & & & & \\
\hline 0.64 & & $\mathrm{t}$ & 5 & 93 & $\mathrm{t}$ & & & \\
\hline 0.26 & & $\mathrm{t}$ & 3 & 4 & & 91 & 1 & $\mathrm{t}$ \\
\hline 0.37 & $\mathrm{t}$ & & 2 & 6 & & 85 & 3 & 3 \\
\hline 0.33 & & & $t$ & 5 & & 93 & $\mathrm{t}$ & 2 \\
\hline 0.26 & & & $\mathrm{t}$ & 7 & & 86 & $t$ & 6 \\
\hline ND & & & (3) & (95) & & (2) & & \\
\hline 0.74 & $t$ & $\mathrm{t}$ & 97 & $\mathrm{t}$ & & & & 2 \\
\hline 0.92 & $t$ & $t$ & 97 & $\mathrm{t}$ & & & & 1 \\
\hline 0.70 & $\mathrm{t}$ & $\mathrm{t}$ & 97 & 1 & & & & 1 \\
\hline $\begin{array}{l}0.61 \\
\text { absent }\end{array}$ & $\mathrm{t}$ & $\mathrm{t}$ & 97 & 1 & & & & 1 \\
\hline
\end{tabular}


Table 3.

\begin{tabular}{|c|c|c|c|c|c|c|c|c|}
\hline \multirow[b]{2}{*}{ Organism } & \multirow{2}{*}{$\begin{array}{c}\text { Total } \\
\text { ubiquinone } \\
\text { content } \\
(\mu \mathrm{mol} / \mathrm{g} \\
\text { dry wt })\end{array}$} & \multicolumn{7}{|c|}{ Percentage of total ubiquinones ${ }^{a}$} \\
\hline & & Q-6 & Q-7 & Q-8 & Q-9 & Q-10 & $\begin{array}{l}\text { Q-10 } \\
\left(\mathrm{H}_{2}\right)\end{array}$ & Others $^{b}$ \\
\hline FR2 & 2.06 & & 1 & 92 & 5 & 1 & & 1 \\
\hline FR3 & 2.22 & & 2 & 94 & 4 & & & $\mathrm{t}$ \\
\hline SA34 & 2.35 & & (3) & (93) & (4) & & & \\
\hline \multicolumn{9}{|c|}{ Rhodopseudomonas capsulata } \\
\hline ATCC 11166 & 5.10 & & & & 1 & 99 & & \\
\hline IL155 & 4.58 & & & & 3 & 95 & 2 & \\
\hline HP8 & 3.96 & & & & 4 & 94 & 2 & \\
\hline $\mathrm{C} 2$ & 4.78 & & & & (4) & (96) & & \\
\hline MC9R & ND & & & & (3) & (97) & & \\
\hline SA47 & ND & & & & 3 & 95 & 2 & \\
\hline \multicolumn{9}{|c|}{ Rhodopseudomonas sphaeroides } \\
\hline ATCC 17023 & 5.14 & & & $\mathrm{t}$ & $t$ & 99 & & \\
\hline IFO 12203 & 5.49 & & & $\mathrm{t}$ & $\mathrm{t}$ & 99 & & \\
\hline B1 & 4.72 & & & & & 100 & & \\
\hline B3 & ND & & & & & 100 & & \\
\hline IL102 & ND & & & & $\mathrm{t}$ & 99 & & \\
\hline RS1 & 5.48 & & & & $\mathrm{t}$ & 99 & & \\
\hline RS2 & 5.08 & & & & $\mathrm{t}$ & 99 & & \\
\hline TWN & 5.68 & & & $\mathrm{t}$ & $\mathrm{t}$ & 99 & & \\
\hline $\mathrm{C} 7$ & ND & & & $\mathrm{t}$ & $\mathrm{t}$ & 99 & & \\
\hline KA38 & 5.82 & & & $\mathrm{t}$ & $\mathrm{t}$ & 99 & & \\
\hline KA63 & 4.81 & & & $\mathrm{t}$ & $\mathrm{t}$ & 99 & & \\
\hline NR3 & 4.98 & & & & & 100 & & \\
\hline \multicolumn{9}{|c|}{ Rhodopseudomonas sulfidophila } \\
\hline W4 & 2.70 & & & $\mathrm{t}$ & $\mathrm{t}$ & 98 & & $\mathrm{t}$ \\
\hline TW13 & 3.08 & & & & (1) & (99) & & \\
\hline \multicolumn{9}{|l|}{ Chromatium vinosum } \\
\hline $\mathrm{D}$ & 4.25 & & 10 & 80 & 1 & 4 & & 5 \\
\hline
\end{tabular}

a Calculated from the peak area on HPLC or on reversed-phase TLC with densitometry (TLC data given in parentheses).

$b$ Unidentified homologues.

$\mathrm{v} / \mathrm{v}$ ), the lipids extracts from all 56 test strains showed a fluorescence-quenching band of the same $R f$ value $(0.2-0.3)$ as the reference ubiquinone. Each of the quinone samples of this fraction had an ultraviolet difference spectrum identical with that of typical ubiquinone (13) with a maximum decrease in absorption at $272-275 \mathrm{~nm}$. Another band that exhibited the same mobility $(R f, 0.5-0.6)$ as vita$\min K_{1}$ was also found in the lipid samples from about one-third of the test strains. The difference spectrum of the quinone samples of this fraction was characterized by a maximum increase in absorption at $245 \mathrm{~nm}$ and a maximum decrease at 263$270 \mathrm{~nm}$, both of which are characteristic of menaquinone (13). 
(Continued)

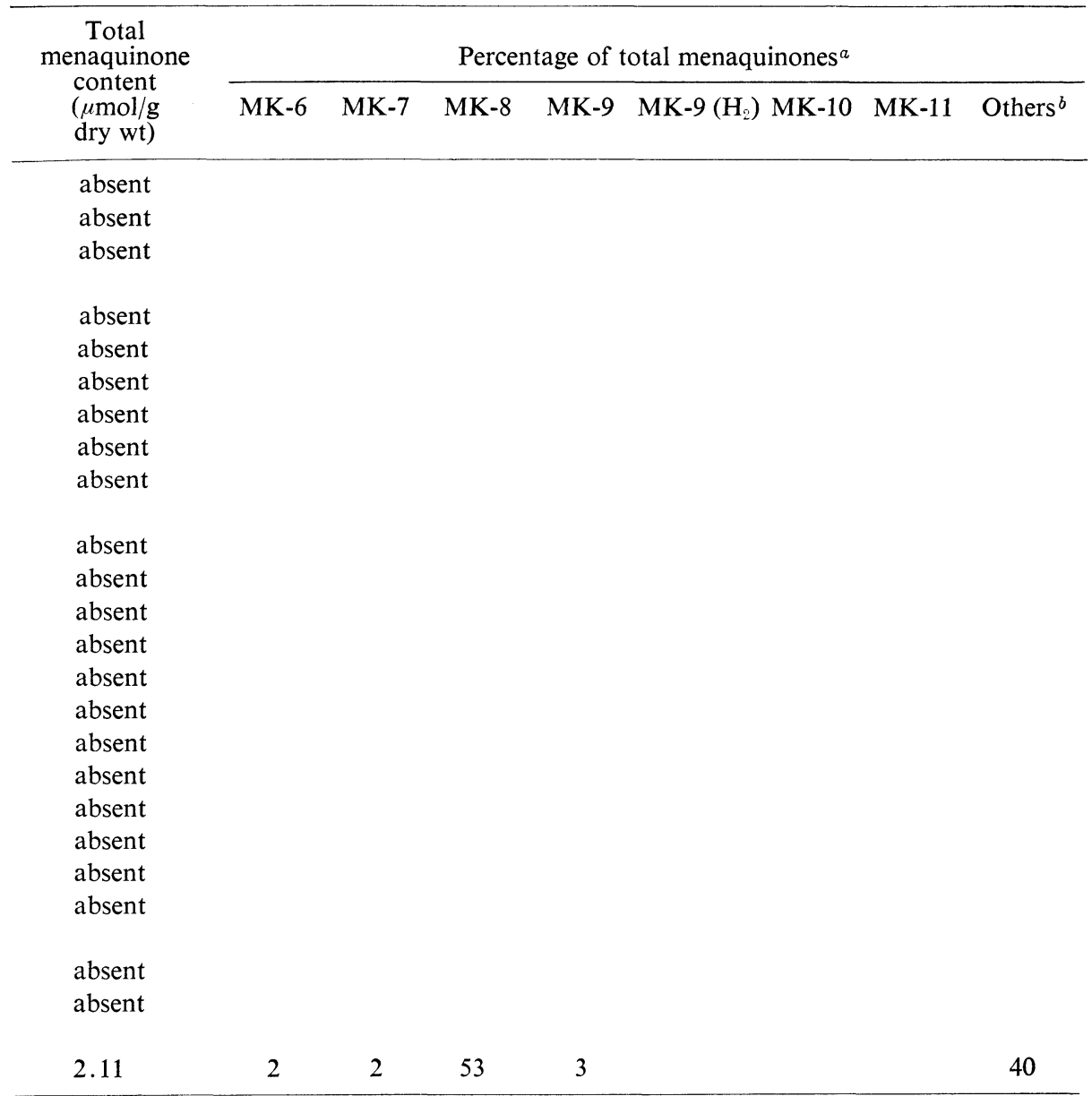

c Trace (less than $1 \%$ of total peak area).

d Not determined.

The reversed-phase TLC and HPLC systems allowed clear separation of the mixtures of the quinone standards. The $R f$ values and HPLC retention times of the quinone homologues in these systems are shown in Table 2. Upon reversedphase TLC, all of the quinone samples from the test strains gave a major band with a $R f$ value that coincided with one of the standard quinone homologues. These results were supported on the whole by the HPLC experiments.

\section{Quinone composition}

The data for the ubiquinone and menaquinone composition of the test strains 
are summarized in Table 3.

Ubiquinones were found in all test strains as mentioned above, with their amounts varying between 2.02 and $5.82 \mu \mathrm{mol} / \mathrm{g}$ dry weight. The length of the polyprenyl side chain of the predominant ubiquinones differed from species to species. Q-10 predominated in all test strains of Rhodospirillum rubrum, Rhodopseudomonas palustris, $R$. acidophila, Rhodopseudomonas capsulata, Rhodopseudomonas sphaeroides, and R. sulfidophila. Q-9 predominated in R. molischianum N131, R. globiformis DSM 161, and all test strains of R. fulvum and Rhodopseudomonas viridis. Q-8 predominated in all test strains of Rhodospirillum tenue, $R$. photometricum, and Rhodopseudomonas gelatinosa. Chromatium vinosum D contained Q-8 as the major ubiquinone. In most strains tested, the predominant ubiquinones accounted for $90 \%$ and more of the total ubiquinone content. Although one to three minor ubiquinones were also found in these organisms, the amount of each minor component was less than $10 \%$ of the total ubiquinone content.

Menaquinones were recovered from $R$. molischianum N131, R. globiformis DSM 161, R. gelatinosa strains ATCC 17011, A3, IL144, and KA49, and all test strains of $R$. tenue, $R$. fulvum, $R$. acidophila, and $R$. viridis. $C$. vinosum $\mathrm{D}$ also contained menaquinones. The total menaquinone content of these strains ranged from 0.26 to $2.11 \mu \mathrm{mol} / \mathrm{g}$ dry weight, corresponding with 5 to $50 \%$ of the total ubiquinone content on the dry weight basis of the same strains. The number of isoprene units of the predominant menaquinones was the same as that of the side chain of the major ubiquinones concurrently present. Namely, MK-10 predominated in the R. acidophila strains, MK-9 predominated in the R. fulvum, R. molischianum, $R$. viridis, and $R$. globiformis strains, and MK-8 predominated in the $R$. tenue and $R$. gelatinosa strains. $\quad C$. vinosum $\mathrm{D}$ had MK-8 as the major menaquinone and a considerable amount ( $40 \%$ of the total menaquinones) of an unidentified homologue that showed a HPLC peak with a retention time of $7.7 \mathrm{~min}$. With the exception of the major component of $C$. vinosum $\mathrm{D}$, the predominant menaquinone constituted 84 to $97 \%$ of the total menaquinone content of each strain.

None of the test strains of $R$. rubrum, $R$. photometricum, $R$. palustris, $R$. capsulata, $R$. sphaeroides, or $R$. sulfidophila produced menaquinones. It is of particular interest that the remaining $R$. gelatinosa strains KE2, FR2, FR3, and SA34 also lacked menaquinones. Concurrent studies have shown that the R. gelatinosa strains devoid of menaquinones differ from typical strains of this species in certain phenotypic characteristics (8).

\section{DISCUSSION}

In view of the present results, the Rhodospirillaceae species studied are divided into the following five categories on the basis of the isoprenoid quinone system: Q-10 - R. rubrum, R. palustris, R. capsulata, R. sphaeroides, and $R$. sulfidophila; Q-10+MK-10 - R. acidophila; Q-9+MK-9 - R. fulvum, $R$. molischianum, $R$. 
viridis, and $R$. globiformis; Q-8 - R. photometricum and $R$. gelatinosa (atypical strains); Q-8+MK-8 $-R$. tenue and $R$. gelatinosa. There has been a general view concerning the quinone system in the Rhodospirillaceae that all species which contain Q-10 lack menaquinones and all species which contain ubiquinones other than Q-10 also possess menaquinones with the corresponding isoprenoid side chain as the second component $(1,5)$. The results of this study extend the earlier results in this area $(1,3-6)$ and provide further evidence that there are some Rhodospirillaceae species that do not fit the above general concept.

Reports on the quinone system in certain species of the phototrophic purple bacteria have been somewhat confusing. Some workers found Q-9 as the major ubiquinone in $R$. rubrum (18), $R$. sphaeroides (4), and $R$. gelatinosa (19), whereas other investigators found Q-10 in the former two species and Q-8 in the latter $(3,5)$. Our results appear to clarify this situation completely. The available information on the quinone composition of $C$. vinosum is also lacking in uniformity. The predominant quinones in this organism reported so far are as follows: Q- $n(20), \mathrm{Q}-7+$ MK- $n$ (18), Q-7+MK-7 (4), Q-8+MK-8 (21), and Q- $n+\mathrm{MK}-8$ (22). Our data clearly indicate that Q- 8 and $\mathrm{MK}-8$ are present as the major quinone components in $C$. vinosum $\mathrm{D}$, which also contains a considerable amount of the unknown menaquinone. At any rate, further studies on additional strains of this species are necessary to clear up this confusion.

As described here, both genera Rhodospirillum and Rhodopseudomonas are considerably heterogeneous groups with respect to the quinone system. This suggests that a taxonomic inconsistency exists in the Rhodospirillaceae. The phenotypic heterogeneity and taxonomic questions which have long existed in these groups of phototrophic bacteria have already been discussed $(23,24)$. Also, recent studies on their phylogenetic traits, e.g., amino acid sequence of cytochromes $c$ (25) and oligonucleotide signature of $16 \mathrm{~S}$ ribosomal RNAs $(26,27)$, have shown that there is no correlation between the phylogenesis and the standard taxonomy of the Rhodospirillaceae. This is not surprising because the genera now defined for the phototrophic purple bacteria are meant to be determinative categories for the identification of newly isolated strains, irrespective of the genetic or evolutional relatedness thereof $(23,24)$. However, we take the ground that, if information is available, a classification system for bacterial species must be based on a combination of phenotypic, chemotaxonomic, and phylogenetic properties, rather than a single one.

To evaluate the significance of the quinone system in Rhodospirillaceae systematics, we attempted to compare the data presented here with those on some phylogenetic and phenotypic properties of these bacteria available in the literature and to re-classify them based on a combination of these characteristics. For this purpose, the available information was arranged in the following manner. First, according to DiCKerson (25), the Rhodospirillaceae species were divided into three groups that have different structural types of $c$-type cytochromes, i.e., "long," "medium," 


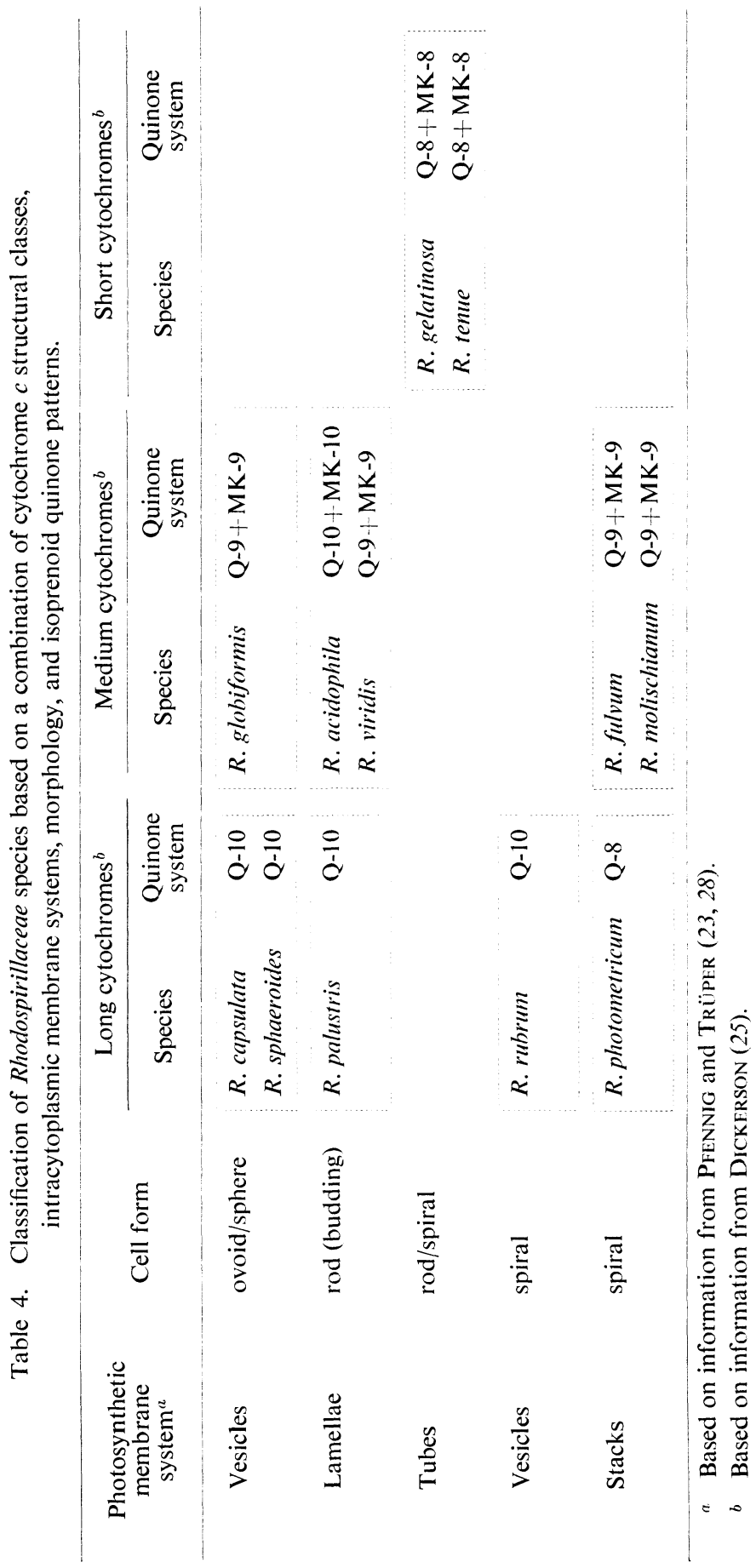


and "short" cytochromes $c$. Second, they were also separated into five groups based on their ultrastructural and morphological characteristics $(23,28)$ - that is, those species that have spherical to ovoid cell forms and vesicular intracytoplasmic membrane systems, those species that have rod-shaped cells multiplying by budding and lamellar membrane systems, those species that have slender rodshaped to spiralloid cells and membrane systems with tubular intrusions, those species that have spiral cell forms and vesicular membrane systems, and those species that have spiral cell forms and several stacks of lamellar membranes. Finally, the Rhodospirillaceae species re-classified on the basis of the above criteria were tabulated with their quinone patterns (Table 4).

The information contained in Table 4 indicates that the Rhodospirillaceae species can be divided into at least eight groups (surrounded by broken lines) based on the new classification system. Interestingly, each of the eight groups is quite uniform in the quinone system, with the exception of the $R$. acidophila-R. viridis group. Since YAMADA et al. (17) suggested that the quinone system might be of value in grouping bacteria at the genus level, it seems logical to conclude that the eight groups of the phototrophic bacteria can be defined as the new genus-groups. $R$. sulfidophila is not listed in Table 4 due to lack of information on its cytochrome $c$ size. However, one would predict that this species is a member of the $R$. capsulata-R. sphaeroides group because of its cell form of the ovoid type, its membrane system of the vesicular type, and its quinone system of Q-10. Also, the atypical $R$. gelatinosa strains that have the quinone system of Q-8 are not tabulated, because they apparently belong to a species different from $R$. gelatinosa. The amino acid sequence analyses of $c$-type cytochromes revealed close affinities between $R$. capsulata and $R$. sphaeroides, between the budding species, between $R$. gelatinos a and $R$. tenue, between $R$. rubrum and $R$. photometricum, and between $R$. fulvum and $R$. molischianum (25). Similar results were obtained with oligonucleotide sequence studies of $16 \mathrm{~S}$ ribosomal RNAs $(26,27)$. The results of these phylogenetic studies with the Rhodospirillaceae encourage our conclusion.

It is evident from the present results that the isoprenoid quinone composition, as well as the conventionally-recognized, phenotypic characteristics of the Rhodospirillaceae yields valuable taxonomic information. Also, whether or not the quinone system in these bacteria is of phylogenetic significance, it seems that in their classification the cytochrome $c$ structural classes and the quinone structural types are correlated. Namely, those species with medium or short cytochromes $c$ generally contain both ubiquinone and menaquinone, whereas those species with long cytochromes $c$ lack menaquinone (Table 4).

In this paper, we did not deal with rhodoquinone, which was initially discovered in $R$. rubrum (29). This type of isoprenoid quinone is also present in certain Rhodospirillaceae species other than R. rubrum, such as $R$. photometricum, $R$. acidophila, and the atypical $R$. gelatinosa strains (HIRAISHI and HoSHINO, in preparation). Further study in this area should provide considerable insight into our un- 
derstanding of the significance of rhodoquinone in Rhodospirillaceae taxonomy.

The authors wish to thank Dr. N. Pfennig, Universität Konstanz, Dr. A. Yoshikawa, Mitsubishi Gas Chemical Co., Dr. H. Takahashi, Tohoku University, Dr. T. A. Hansen, University of Groningen, and Dr. K. Shimada, Tokyo Metropolitan University, for supplying the cultures. Special appreciation is extended to Drs. H. Kuraishi and Y. Katayama-Fujimura and their coworkers of Tokyo University of Agriculture and Technology for their cooperation in the HPLC analysis.

\section{REFERENCES}

1) M. D. Collins and D. Jones, Microbiol. Rev., 45, 316 (1981).

2) Y. Yamada and H. Kuraishi, In Methods in Microbial Chemotaxonomy, ed. by K. KomaGaTA, Japan Scientific Societies Press, Tokyo (1982), p. 143.

3) N. G. CARr and G. EXell, Biochem. J., 96, 688 (1965).

4) K. Takamiya, M. Nishimura and A. Takamiya, Plant Cell Physiol., 8, 79 (1967).

5) J. Maroc, H. De Klerk and M. D. Kamen, Biochim. Biophys. Acta, 162, 621 (1968).

6) H. G. Trüper and N. Pfennig, In The Photosynthetic Bacteria, ed. by R. K. Clayton and W. R. Sistrom, Plenum Press, New York (1978), p. 19.

7) V. B. D. Skerman, V. McGowan and P. H. A. Sneath, Int. J. Syst. Bacteriol., 30, 225 (1980).

8) A. Hiraishi and H. Kitamura, Bull. Jpn. Soc. Sci. Fish., 50, in press.

9) N. Pfennig, J. Bacteriol., 99, 597 (1969).

10) T. A. Hansen and H. VeldKamp, Arch. Mikrobiol., 92, 45 (1973).

11) N. Pfennig, Arch. Mikrobiol., 100, 197 (1974).

12) M. D. Collins, T. Pirouz, M. Goodfellow and D. E. Minnikin, J. Gen. Microbiol., 100, 221 (1977).

13) A. KRÖGER, Methods Enzymol., 53, 579 (1978).

14) J. Tamaoka, Y. Katayama-Fujimura and H. Kuraishi, J. Appl. Bacteriol., 54, 31 (1983).

15) H. Oyaizu and K. Komagata, J. Gen. Appl. Microbiol., 27, 57 (1981).

16) H. Oyaizu, K. Komagata, A. Amemura and T. Harada, J. Gen. Appl. Microbiol., 28, 369 (1982).

17) Y. Yamada, G. Inouye, Y. Tahara and K. Kondo, J. Gen. Appl. Microbiol., 22, 203 (1976).

18) R. L. Lester and F. L. Crane, J. Biol. Chem., 234, 2169 (1959).

19) K. SASAKI and S. NAGAi, J. Ferment. Technol., 57, 383 (1979).

20) Y. D. Halsey and W. W. Parson, Biochim. Biophys. Acta, 347, 404 (1974).

21) L. K. Osnitskaya, D. R. Threlfall and T. W. Goodwin, Nature, 204, 80 (1964).

22) M. B. Hale, R. E. Blankenship and R. C. Fuller, Biochim. Biophys. Acta, 723, 376 (1983).

23) N. Pfennig, Ann. Rev. Microbiol., 31, 275 (1977).

24) N. Pfennig and H. G. Trüper, Ann. Microbiol. (Inst. Pasteur), 134B, 9 (1983).

25) R. E. Dickerson, Nature, 283, 210 (1980).

26) J. Gibson, E. Stackebrandt, L. B. Zablen, R. Gupta and C. R. Woese, Curr. Microbiol., 3, 59 (1979).

27) C. R. Woese, J. Gibson and G. E. Fox, Nature, 283, 212 (1980).

28) H. G. Trüper and N. Pfennig, In The Prokaryotes, ed. by M. P. Starr, H. Stolp, H. G. Trüper, A. Balows and H. G. Schlegel, Springer-Verlag, Berlin (1981), p. 299.

29) J. Glover and D. R. Threlfall, Biochem. J., 85, 14P (1962).

30) N. Pfennig, J. Bacteriol., 99, 619 (1969).

31) J. S. Kim, K. Ito and H. Takahashi, Agric. Biol. Chem., 44, 827 (1980).

32) K. Watanabe, J. S. Kim, K. Ito, L. Buranakarl, T. Kampee and H. Takahashi, Agric. Biol. Chem., 45, 217 (1981). 